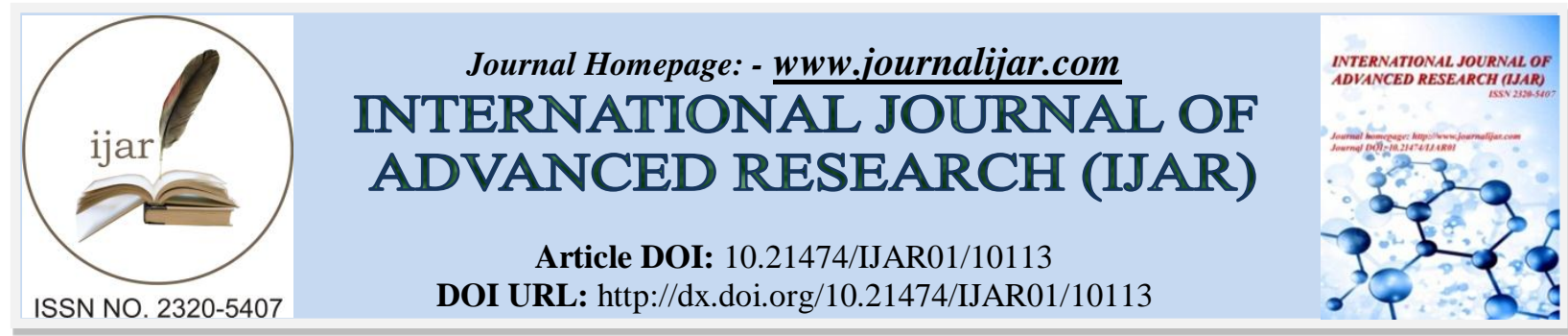

RESEARCH ARTICLE

\title{
COMPENSATION SCHEME AND EMPLOYEE PERFORMANCE OF PUBLIC MEDICAL HEALTH CARE WORKERS IN VIHIGA COUNTY, KENYA.
}

Jane Morine Nyonje and Oluoch Mercy Florah.

\section{Manuscript Info}

\section{Manuscript History}

Received: 14 September 2019

Final Accepted: 16 October 2019

Published: November 2019

\section{Key words:-}

Compensation Scheme, Employee Performance, Public Medical Health Workers, Vihiga County, Kenya .
Abstract

Globally organizations are made up with human resources who are regarded to be one of the most essential resources of today's firms and if well managed can give a firm competitive advantage over other firms in the same industry. Compensation scheme plays an important role since it is at the heart of the employment relationship, being vital to both employers and employees, and is seen as one of the most significant ways that is effective in increasing health workers performances in terms of quality of services, efficiency and attendance at their work which is why matters on compensation scheme should be addressed. The study examined the influence of compensation scheme on employee performance of public medical health care workers in Vihiga County. The study was guided by expectancy theory, equity theory and reinforcement theory. The study adopted a cross sectional survey. The target population comprised of 518 public medical health care providers and a sample size of 84 public health medical care officers. The study employed a stratified and simple random sampling technique to select the respondents. The study used primary data through the use of questionnaires as research instrument. The researcher quantified quantitative data by use of percentages, frequencies, means and standard deviations. Multiple linear regression analysis was also used to show relationships between variables. The study revealed a positive and significant influence on employee performance with $(\beta=0.234 ; p<0.05)$, basic salary had a positive and significant influence on employee performance with $(\beta=0.346 ; p<0.05)$ and allowances had positive and significant influence on employee performance with $(\beta=0.257 ; \mathrm{p}<0.05)$. Bonuses has an influence on employee performance however the county hospital does not provide regularly salary supplements inform of bonus hence affecting their efficiency at work, basic salary raises are rare in the county thus it has affected their efficiency at work and that allowances pay based on the employees skill employee affects employee's performance. The researcher recommends that allowances should be awarded in a way that is fair to all cadres of staff and job evaluation should be conducted in order to enhance harmonization of salary. The study further suggests that more research needs to be done on the same area but concentrate on other factors influencing employee performance of county governments and even the private sector such as banks and manufacturing companies for the purpose of comparing. It is expected 
that the findings of the study will provide valuable information to the County Government of Vihiga as a guideline on the most effective policies and practices of compensating employees that the county can utilize to enhance employee performance. This study will contribute knowledge to existing literature in compensation and employee work performance. It will also act as a motivator for further research to other researchers and academicians in refining and extending the present study especially in Kenya.

Copy Right, IJAR, 2019,. All rights reserved.

\section{Introduction:-}

The people who build up an organization are human resources who are regarded to be one of the most essential resources of today's firms (Markova \& Ford 2014). Organizations today operate in an environment that is highly competitive and so dynamic to continue remaining important in the market; they should be capable of responding quickly to ever changing demands of employees (Hakala, 2016). Compensation is one of the ways employed by organizations to attract and retain employees who are suitable by facilitating them to enhance their service delivery and performance through motivation and complying with the regulations and legislation of employment (Prasetya\& Kato, 2014). It is the most essential components which motivate employees to offer their best effort to come up with ideas that are innovative which may lead to a better functioning of the organization and in addition improving both individual and organizational performance financially and non-financially. According to Ahmed, Ullah, \& Ahmed, (2015) there are other ways of compensating an employee that do not only focus on financial compensation and some of these are the employee appraisal they are able to gain from their management, the opportunity to undertake an important project or task, and even attention in leadership. Therefore both financial and non-financial compensation have been found to positively be associated with performance of employees, productivity, organizational citizenship behaviors turnover and satisfaction (Ahmed et al, 2015). Hence, rewarding employees in terms of salaries and allowances/bonuses in any organization controls the work pattern and behavior hence a main motivating force towards employee performance (Agarwal, 2008).

This study was anchored on the Expectancy Theory propagated by Vroom (1964), Equity Theory proposed by Adams in (1963) and Reinforcement Theory by Skinner (1953). According to Expectancy theory employees have expectations while they are performing their duties at work (Vroom, 1964). Employees are triggered to behave in a certain way when they are motivated by something (Ekerman, 2010). Expectations are created into the employment relationship, the foundation of which, according to the reward point of view, is the responsibility of an employee in providing knowledge, skills and effort to their employer, and in return, the employer will provide the employee with a wage or a salary, this then will raise the efficiency, effectiveness, and quality work of the employee whose expectations and needs would have been met, (Armstrong \&Taylor, 2014). Equity theory speculates that since employees in an organization are expecting to be rewarded or compensated like other employees for the same levels of input, the rewards distribution happen to be significant. It is the perceiving equity of the balancing of effortreward that is important and is used to determine the performance level of employees therefore the theory puts emphasis on equity in structure of pay and compensation of employees (Adams, 1963). Reinforcement theory postulates that any response followed by a reward will probably recur in the future since behaviours which have an experience that is rewarding are likely to be repeated. The implication for compensation is that effective performance of employee followed by financial compensation will make future performance of employees likely improved (Skinner, 1953). Since2016, there have been lots of strikes in the health sector in Kenya. They have majorly been in the Public Sector most of them attributed to the salary that the health care workers earn. As the health care workers execute their duties, they are entitled to various allowances which form part of their salary. Vihiga County has an average of 518 medical health care workers working in various cadres in the medical field. They are distributed in its 55 facilities spread across the county.

Vihiga County health sector is no exception when health workers in March, 2019 went on strike due to poor pay where the employees were demanding a salary increase and promotion. This shows that the management and Human Resources of the county have ignored the needs of the health workers in terms of the salaries which has affected the quality of services and efficiency hence leading to too much complaints from the members of public in the county. Worst still the aspect of rewards more so pay has never been given the attention it deserves to match the workload. In 2019, failure to pay the officers their allowances led to a strike which paralyzed service delivery. There is need 
therefore to mitigate the occurrence of these strikes and one way to do this is by ensuring that the health care workers are well paid.

\section{Concept of Compensation Scheme}

Employee compensation schemes, including bonus payments and other rewards, are used to recompense workers for their services in accordance with their performance, and as a means of motivating them towards achieving organisational goals. A well designed compensation scheme may be used to motivate employees towards achieving more ambitious goals and also attract and retain top talent in an organisation.

Compensation is rewarding employees according to their job and includesbonuses, commissions advance, salary and wages given to employees. Compensation is certainly the most significant element of communication within an organization. Compensation is the main factor in performance of any employee or organization (NnajiIhedinmah\&Egbunike, 2014). High satisfied jobs that result from rewards given in relation to a job did enable employees to put more focus on their responsibilities hence increasing their performance (Muchiri, 2016). System of compensation that is effective and sound has the capacity and helps in attracting the right type of human resource (Gerhartet al., 1995).The fit between compensation system characteristics and employee performance are proven to be significant (Ali, Edwin \&Tirimba, 2015). The distinguished factors of pay are tangible benefits and non-tangible benefits, fixed pay and performance based pay, skill based pay and job based pay, rigid and flexible benefit plans. Salary is a significant aspect of compensation because it also affects retirement and an employee needs to feel the effort through hardworking they are putting into their work and this should match what they are paid as salary.

Surbhi (2015) compensation are the aggregate winning a labourer gets for the execution of administrations inside a timeframe while salary is a fix payment to employees on weekly, monthly or annual rate of pay. Wages are equivalent to the result of hourly rate, times the amount of pieces notwithstanding houses, premiums and coincidental points of interest.Heathfield (2017) states that salary is the amount of paid hourly or salary that an employee will receive for the work performed in any organization. Okoth (2014) stated that a significant number of employees state that salary payment that is fair is the single most significant thing they need from their organization. An appropriate employee's salary scale is thus essential for better performance of employees.

Incentive plans are additional remunerations given to workers over their normal wages and compensations. These incentives can be advice of rewards, profit sharing and merit pays. Incentive designs can be used as a reward for finishing specific targets set by the association, or for sense of duty regarding the association. Heathfield (2016) suggests incentive designs are remuneration well past the measure of pay or hourly rate of pay.

Mamdani and Minhaj (2014) pointed out that commission is another important component of compensation and this includes earning of employees based on some form or volume of performance are employed whereby the risks are shifted from the employer to an employee. Bonuses are earnings of employees as rewards for improving productivity, special achievements and profit raise (Reddy \&Karim, 2014). Condly, Clark and Stolovitch (2013) examined that bonuses work like investments, whereby employees being rewarded a bonus will generally increase the work input of an employee and simply encouraging them to work even better in future.

There are non-financial ways that employers use to compensate their employees, they include; employee benefits and additional privileges. Employee benefits for example, life and medical coverage, pension and retirement plans, and perquisite, for example transportation or company cars represent a significant pay component in most extensive firms. Notwithstanding tax advantages and purchasing economies of scale that make it monetarily beneficial for the firm to give benefits as a method of pulling in and holding wanted employees. Employees in organisations may enjoy additional privileges for example the utilization of organisation vehicles, club enrolment, travelling allowance, acknowledgment and opportunities for training and development. This study considered salary/wages, allowances and incentives/bonuses as the variables of compensation scheme.

\section{Concept of Employee Performance}

Employee performance is the capability of employees to accomplish or achieve their targets based on the organizational expectations (Oriane, 2015). Pierce et al,(2004) state that performance of an employeeis the efficiency and effectiveness to which employees of any given company can undertake their day to day responsibilities and duties in order to meet the expectations of customers as well as management. It is also the level to which the employees can apply their skills, attitude and knowledge in order to meet the specified objectives and 
achieve the desired results(Rehman, 2009). Okumbe (1998) states that performance of employees refers to the level of achievement based on a given standard or criteria and are a function of motivation and ability.

Bohnstedt and Larsen, (2008) postulates that employee performance is often measured indirectly using employee behavior aspects at work like managing time, etiquette, consistency, precision, speed, influence on other employees and courtesy. However, other scholars propose the measurements of employee performance to include customer satisfaction that is measured through customer feedback and the number of loyal customers; quality that is measured by work output percentage that cannot be accepted or must be redone (Muchiri, 2016).Scott (2016) states that attendance of employees affect the productivity of the organisation.It is therefore fundamental for an organisation to consider tracking how employees are reporting to the workplace.

Timeliness can be measured interms of how fast an employee performs the work or certain task given; tardiness or absenteeism is observed when employees decide to absent themselves from working. Work place absenteeism of one employee will force the others to ensure adjusting the missing part whichleads to overworking of other employees hence productivity will be low. Thus, attendance is essentialin ensuring sustainability of performance (Root, 2016). Muchiri, (2016) states that objective achievement is measured when there are improved set targetsbyan employee, then the employee is regarded as to have performed well to attain the objectives.

Scott (2016) states that " the way quality work is completed reflects the commitment and passion of an employee toward what they are undertaking in the working place therefore persistency of employees to deliver quality results can be very delicate in trying to attain performance". The employees' initiative is significant to an organisation as it helps the organisation in identifyingbest practices thus enabling the organisation to remain competitive and maintain customers. Efficiency is the outcome of employee's performance and how that is perceived by the customers, employer, and management and even colleagues hence output that meets the quality standards is what efficiency means".This study looked atefficiency, quality service, initiative and attendance as performance variables.

\section{Public Health Sector in Vihiga County Kenya}

The advent of devolution in 2010 brought about the highest and newest type of decentralization in Kenya. In 2013 health sector was the major service sector that was devolved under the new arrangement of governance. The principle for devolving the sector was to let the county governments to design models that are innovative and interventions that are suitable to the health needs in their contexts, encouraging effective participation of citizen and making autonomous and quick decisions on mobilization and management of resources. In the health sector, health service delivery that are essential was allocated to county governments, whereas the national government retained policies related to health, counties technical assistance, and managing of health facilities of national referrals. However, the sector in nearly all counties is currently faced with massive challenges that range from gaps in capacity, deficiency of human resource, lack of institutional and legal infrastructure, uncontrolled corruption and conflict relationship that is associated with the national government.

There are great discrepancies between the health personnel numbers per county who offer health services in facilities. Overall, the ratio of healthcare providers to the population falls below the WHO recommendation of two hundred and thirty $(230)$ per one hundred thousand $(100,000)$ people, and in 2010 stood at one hundred and sixty nine (169) per one hundred thousand $(100,000)$, but this compares favourably to other African countries in the region such as Mozambique, Uganda, Tanzania, and Malawi(Government of Kenya 2010). The inadequate health personnel in most counties has been one of the major contributing factor to the recent unrest in the county's health sector.

Vihiga County has an average of 518 workers working in various cadres in the medical field. They are distributed in its facilities spread across the county. Currently, the department has a total of fifty five (55) public health facilities which consist of thirty three (33) dispensaries, three (3) hospitals and eighteen (18) health centers. They are all well spread within the entire county within a radius of less than five kilometres apart. The department has and is still realizing very important achievements since its inception. This includes, establishment of county medical training college in collaboration with Kenya Medical Training College, currently with a total of 200 students whereby the majority comes from the county; opening of 3 new dispensaries; procurement of 3 fully equipped ambulances to aid patients emergency and referral services; construction of an oxygen plant at county referral hospital and modernization of the mortuary is ongoing; installation of a CT scan, employment of various health workers in a variety of cadres, procurement of assorted equipment for public health facilities; completion of 20 stalled health projects; renovations and improvement works in 5 public health facilities; procurement of drugs, non 
pharmaceuticals and other medical commodities necessary for quality health care (Vihiga County Integrated Plan, 2018).

In 2018,Vihiga County implemented the Salaries and Remuneration Commission circular on health care workers allowances which included; emergency call allowance, extraneous allowance,health risk allowance, non- practising allowance and uniform allowance, The rates were specific for particular cadres of medical health care workers among them being medical officers, clinical officers, pharmacists, clinical officers, nurses and laboratory staff. The strategic direction is to improve, upgrade and equip the existing facilities without opening any other new one in order to gain optimum output from the available human resources, financial resources and infrastructure which includes buildings, equipment and technology. In addition, the department has upgraded six health facilities in the five sub counties to hospitals that can provide level four hospital services. The county referral hospital is still being modernized and plans are at an advanced stage to commence construction of a six storey plaza that will house various wards that will accommodate a capacity of 160 beds including executive wing, several theatres, ICU unit, Dialysis unit, administration offices and medical school classes among others. More specialists will be employed and more sophisticated diagnostic equipment will be procured for managing patients with chronic diseases.

\section{Research Objective:-}

The study objective was to determine the influence of compensationscheme on employee performance of public medical health care workers in Vihiga County, Kenya.

\section{Compensation Scheme and Employee Performance}

Various studies have been done on the area of compensation and employee performance. Globally, a research study byAslam et al (2015) on impact of reward system and compensation on performance of an organization in the Pakistan banking sector established that, incentive, salary/wage do not give reliable results on employees performance. A study byEdirisooriya (2014) on the impact of intrinsic and extrinsic rewards on employee performance ofElectriCo in Sri Lanka where primary data that included self designed questionnaire was utilized to collect data, data was analyzedemploying descriptive and inferential statistics and 100 employees was chosen from 1075 employees as a sample representative. The study findings revealed that there is a positive correlation between intrinsic, extrinsic reward and performance of an employee. Regionally, Ojeleye (2017) study on the impact of remuneration on performance of employees of Polytechnic of Abdul Gusau in Nigeria and found out that there is a positive and strong association between remuneration and performance of employees' and that salaries/wages and bonuses/incentives also served as a type of employee motivation hence improved performance.Sajuyigbe, Olaoye\&Adeyemi (2013) investigated the influence of reward on performance of employees' in selected manufacturing firms in Ibadan, Nigeria where closed ended questionnaire was employed in collecting information from one hundred (100) respondents. Purposive sampling was utilized and data analyzedusing multiple regression and result findings indicated that dimensions of reward jointly predicts performance of employees which accounted for seventy one percent $(71 \%)$ variance of employee performance.

Oyiraet al (2015) did a study on the effect of reward system on performance among health care workers in the university of Calabar Teaching Hospital in Nigeriawheredesk survey was utilized to gather information that was critical and relevant, primary sources included interview, questionnaire and observation whereas secondary data were collected from the libraries, internet, journals and textbooks, chi-square was employed and the findings established that the rewards in terms of monetary had an impact that is positive on performance of employees while non-monetary rewards had an effect that is negative on performance of employees.

Locally a study by Nyaribo (2016) on the influence of non-financial compensation on performance of employees of micro financial institutions with reference to WakenyaPamoja Sacco in Kisii County revealed that, the short- term incentive pay offers the power job short- oriented. The study also established that motivating an individual through compensation related to performance enhances the performance of employees and it based on the accountability of the organization and measuring output of an individual output.Shilongo (2013) study on the influence of pay related to performance on employeesat the Motor Vehicle Accident Fund in Kenya and the findings indicated that pay related to performance directly affected the workers performance, created the output by paying and workers were more able to give structure of pay according to their performance. 


\section{Research Design}

A descriptive cross sectional survey was adopted for the purpose of this study. Cross-sectional surveys are studies aimed at establishing the level or frequency of a certain attribute in a definite population at a particular time (Lotta, 2012).The design isalso essential to assess the beliefs, attitudes, knowledge and practices of an entire population or a subset is thereof selected, and thus from these individuals, data is collected to assist in answering theinterested research questions (Kothari, 2004).Thuita (2018) successfully used this design to explore on the aspect of compensation scheme and employee performance while Ndede (2014) too used the research design to establish the reward management and its effects on employee performance in North Coast Kenya.

\section{Population of Study}

The target population comprisedof 518public medical health care provides working at each of the five main health care facilities in the five Sub- Counties of Vihiga namely Luanda, Emuhaya, Vihiga, Sabatia and Hamisi. Key informants likethe In- Charge at the main Sub- County Health facility or Supervisors were also targeted.

\section{Sample Design}

Sample size is the item number that should beconsidered from the population to make up a sample (Kothari, 2004). Mugenda and Mugenda (2003), refers it to a sub-set of a particular population. Kitchenham and Pfleeger (2002) state that valid and good sample should represent the population. Nassiuma (2000) sample formula was used to calculate the sample sizedemonstrated as follows:

$$
\mathrm{n}=\frac{\mathrm{NC}}{\mathrm{C}^{2}+(\mathrm{N}-1) \mathrm{e}^{2}}
$$

Where: $\mathrm{N}, \mathrm{n}, \mathrm{C}$, e represents the population, sample size, the coefficient of variation of 0.5 , and the precision level of 0.05 respectively.

The formula was used in calculating the sample as shown

$$
\begin{aligned}
& \mathrm{n}=\frac{518 \times 0.5^{2}}{0.5^{2}+(518-1) 0.05^{2}} \\
& \mathrm{n}=\frac{518 \times 0.25}{0.25+(518-1) 0.0} 025 \\
& \mathrm{n}=\frac{129.5}{0.25+1.2925} \\
& \mathrm{~N}=84
\end{aligned}
$$

Therefore, a sample size of 84 public medical health care workers was chosen.

Table 3.1:-Target Population

\begin{tabular}{|l|l|c|c|}
\hline No & Strata & Target Population & Sample Size \\
\hline 1 & Specialist Doctors & 6 & 1 \\
\hline 2 & Medical Officers & 31 & 5 \\
\hline 3 & Dentists & 1 & 1 \\
\hline 4 & Pharmacists & 9 & 2 \\
\hline 5 & Clinical Officers & 91 & 15 \\
\hline 6 & Nurses & 320 & 50 \\
\hline 7 & Laboratory Staff & 60 & 10 \\
\hline & Total & $\mathbf{5 1 8}$ & $\mathbf{8 4}$ \\
\hline
\end{tabular}

Source: (Vihiga County HR Records, 2019)

The study usedstratifiedand simple random sampling method in selecting the respondents from each of the five SubCounties i.e Luanda, Vihiga, Sabatia, Hamisi and Emuhaya. Stratified sampling technique was used to group respondents into stratas which included specialist doctors, medical officers, dentists, pharmacists, clinical officers, 
nurses and laboratory staff. For the exact individuals to take part in participating in the study, the researcher employedsimple random sampling technique as it offered every employee in the county an equal chance to be included in the sample.

\section{Data Collection}

The study usedprimary data. Primary data was conducted through the use of questionnaires. Primary data was collected using open and close ended questionnaire that wereconstructed using a five-point Likert Scale. The questionnaires were issued using the technique of drop and pick in order to allow the selected respondents to fill in at their convenience. The questionnaire was divided into the main areas of the research except the first part which captured the respondent's personal characteristics. The other questionnaire sections were organized according to the major specific objectives related to compensation scheme and employee performance.

\section{Data Analysis}

Completeness and consistency of the data collected was done where both descriptive and inferential statistics were used. The researcher quantified quantitative data by use of percentages, frequencies, means and standard deviations. The results were presented by use of tables for salient variables using statistical software SPSS Version 22. Multiple linear regression analysis was completed to establish if the linear combinations of bonuses, basic salary and allowances significantly affect employee performance. The linear regression equation was presented as follows:

$\mathbf{Y}=\boldsymbol{\beta}_{0}+\boldsymbol{\beta}_{1} \mathbf{X}_{1}+\boldsymbol{\beta}_{2} \mathbf{X}_{2}+\beta_{3} \mathbf{X}_{3}+\varepsilon$

Where

1. Y represents Employee Performance (Dependent Variable)

2. $\beta_{0}$ represents Constant of regression

3. $\beta_{1}, \beta_{2}, \& \beta_{3}$ represents Coefficients of Independent variables

4. $\mathrm{X}_{1}$ represents Bonuses

5. $\mathrm{X}_{2}$ represents Basic Salary

6. $\mathrm{X}_{3}$ represents Allowances

7. $\boldsymbol{\varepsilon}$ represents Error term.

\section{Response Rate}

Response rate also referred to as return rate or completion rate is the number of people who were involved in answering the questionnaire divided by the number of people in the sample (Dillman, 2011). A total of 84 questionnaires were administered to public medical healthcare workers found in Vihiga County, Kenya. Out of the 84 questionnaires, 77 questionnaires were filled correctly and returned. This represented a response rate of $91.7 \%$ which is good as posited by Kothari (2014) that a response rate which is greater than $50 \%$ is considered good for analysis. The results for return rate are as presented in Table 4.1 below.

Table 4.1:-Response Rate

\begin{tabular}{|l|l|l|}
\hline Response Rate & Frequency & Percent \\
\hline Issued Questionnaires & 84 & 100 \\
\hline Filled and Returned & 77 & 91.7 \\
\hline
\end{tabular}

\section{Demographic Information}

This section discusses information related to the characteristics of the respondents included in the study including the respondents' age, gender, educational level, designation and work experience the respondents' have been working in the county.

\section{Distribution of the Respondents by Gender}

The study was carried out to determine the respondent's gender to enable the researcher in establishing whether there is gender parity among the public health care workers in Vihiga County. The study findings as indicated in Table 4.2 indicates that majority of the respondents $48(62.3 \%)$ were female and $29(37.7 \%)$ were male. The findings revealed that a majority of the respondents who participated in the study were female since in the medical sector and field the female gender are more than male counterparts especially in lower cadres and more especially they were female nurses.

Table 4.2:-Distribution of the Respondents by Gender

\section{Gender}

Frequency
Percent 


\begin{tabular}{|l|c|c|}
\hline Male & 29 & 37.7 \\
\hline Female & 48 & 62.3 \\
\hline Total & $\mathbf{7 7}$ & $\mathbf{1 0 0 . 0}$ \\
\hline
\end{tabular}

Distribution of the Respondents by Age

The respondents were asked to specify their age bracket in which they were distributed. The study results as shown in Table 4.3 indicated that $3(3.9 \%)$ of the respondents were of age bracket of 20-25 years, 6(7.8\%) were falling between the age of 26-30 years and 20(26\%) were between 31-35 years of age. The study findings also indicated that majority of the respondents 37(48.1) were of the age bracket of 36-40 years and the remaining 11(14.3\%) were 41 years and above. The study results implied that the medical health workers at the county government of Vihiga are made up of different age groups who participated in the study.

Table 4.3:-Distribution of the Respondents by Age

\begin{tabular}{|l|c|c|}
\hline Age & Frequency & Percent \\
\hline $20-25$ Years & 3 & 3.9 \\
\hline $26-30$ Years & 6 & 7.8 \\
\hline $31-35$ Years & 20 & 26 \\
\hline $36-40$ Years & 37 & 48.1 \\
\hline Above 41 Years & 11 & 14.3 \\
\hline Total & $\mathbf{7 7}$ & $\mathbf{1 0 0 . 0}$ \\
\hline
\end{tabular}

Distribution of the Respondents by the Highest Level of Education

The respondents were requested to state their highest educational level to establish if employee performance is influenced by the education level that the medical health workers posses. The results as shown on Table 4.4 indicates that majority $39(51 \%)$ of the respondents possess diploma, $27(35 \%)$ of the respondents were degree holders, 5(6\%) have postgraduate degrees and the remaining 6(8\%) had PHD as their highest education level.

Table 4.4:-Distribution of the Respondents by the Highest Level of Education

\begin{tabular}{|l|c|c|}
\hline Age & Frequency & Percent \\
\hline Diploma & 39 & 51 \\
\hline Degree & 27 & 35 \\
\hline Postgraduate & 5 & 6 \\
\hline PHD & 6 & 8 \\
\hline Total & $\mathbf{7 7}$ & $\mathbf{1 0 0 . 0}$ \\
\hline
\end{tabular}

\section{Distribution of the Respondents by Work experience}

The respondents were requested to indicate the duration in which they have worked in Vihiga County as medical health workers to assess whether work experience has an influence on employee performance. The study findings as shown on Table 4.5 indicates that $8(10.4 \%)$ of the respondents have been working in the county for a period below 3years, majority $35(45.5 \%)$ of the respondents have worked for a period between 3-6 years and 34(44.2\%) of the respondents have been working for above 7 years.

Table 4.5:-Distribution of the Respondents by Work experience

\begin{tabular}{|l|c|c|}
\hline Work Experience & Frequency & Percent \\
\hline Below 3 years & 8 & 10.4 \\
\hline 3-6 years & 35 & 45.5 \\
\hline 7 years and above & 34 & 44.2 \\
\hline Total & $\mathbf{7 7}$ & $\mathbf{1 0 0 . 0}$ \\
\hline
\end{tabular}

\section{Distribution of the Respondents by Designation}

The respondents were requested to indicate their respective designation within the County to determine whether designation has an influence on performance of the publicmedical health care workers. The study findings as shown on Table 4.6 indicates that $1(1.3 \%)$ of the respondents were specialist doctors, $5(6.5 \%)$ were medical officers, $1(1.3 \%)$ were dentists, $2(2.6 \%)$ were pharmacists, $15(19.5 \%)$ were clinical officers, majority $43(55.8 \%)$ were nurses and the remaining $10(12.9 \%)$ were laboratory staff. 
Table 4.6:-Distribution of the Respondents by Designation

\begin{tabular}{|l|c|c|}
\hline Designation & Frequency & Percent \\
\hline Specialist Doctor & 1 & 1.3 \\
\hline Medical Officer & 5 & 6.5 \\
\hline Dentist & 1 & 1.3 \\
\hline Pharmacist & 2 & 2.6 \\
\hline Clinical Officer & 15 & 19.5 \\
\hline Nurse & 43 & 55.8 \\
\hline Laboratory Staff & 10 & 12.9 \\
\hline Total & $\mathbf{7 7}$ & $\mathbf{1 0 0 . 0}$ \\
\hline
\end{tabular}

\section{Descriptive statistics for Bonuses on Employee Performance}

The study found it important to determine the influence of bonuses on employee performance. The researcher's interest was on the views of the respondents on the extent to which the sub-constructs of bonuses affect employee performance as shown in Table 4.6. The respondents were asked to specify their responses using a 5 point likert scale of (1)-Strongly Disagree (SD); (2)-Disagree(D), (3)-Neutral(N), (4)-Agree(A) and (5)-Strongly Agree(SA). Frequency and percentage for each response were noted as shown on the tables below.

Table 4.7:-Descriptive statistics Results for Bonuses on Employee Performance

\begin{tabular}{|c|c|c|c|c|c|c|c|c|c|c|}
\hline & Statement & & SA & A & $\mathrm{N}$ & $\mathrm{D}$ & SD & Total & Mean & Std.D \\
\hline \multirow[t]{2}{*}{ I } & \multirow{2}{*}{$\begin{array}{l}\text { The hospital provides regularly salary } \\
\text { supplements inform of bonus hence } \\
\text { improving my efficiency at work. }\end{array}$} & Freq & 3 & 0 & 0 & 24 & 50 & 77 & \multirow[t]{2}{*}{2.99} & \multirow[t]{2}{*}{1.400} \\
\hline & & $\%$ & 3.9 & 0 & 0 & 31.2 & 64.9 & 100 & & \\
\hline \multirow[t]{2}{*}{ ii } & \multirow{2}{*}{$\begin{array}{l}\text { Reallocation of financial incentives like } \\
\text { bonuses is donein a transparent manner and } \\
\text { fairly. }\end{array}$} & Freq & 0 & 32 & 0 & 0 & 45 & 77 & \multirow[t]{2}{*}{2.75} & \multirow[t]{2}{*}{1.488} \\
\hline & & $\%$ & 0 & 41.6 & 0 & 0 & 58.4 & 100 & & \\
\hline \multirow[t]{2}{*}{ iii } & \multirow{2}{*}{$\begin{array}{l}\text { Payment of bonuses is based on the period } \\
\text { of time one has been working in the county. }\end{array}$} & Freq & 11 & 0 & 15 & 25 & 26 & 77 & \multirow[t]{2}{*}{2.30} & \multirow[t]{2}{*}{1.082} \\
\hline & & $\%$ & 14.3 & 0 & 19.5 & 32.5 & 33.8 & 100 & & \\
\hline \multirow[t]{2}{*}{ iv } & \multirow{2}{*}{$\begin{array}{l}\text { Bonuses payment is related to the output or } \\
\text { volume produced }\end{array}$} & Freq & 0 & 0 & 12 & 22 & 43 & 77 & \multirow[t]{2}{*}{2.59} & \multirow[t]{2}{*}{1.100} \\
\hline & & $\%$ & 0 & 0 & 15.6 & 28.6 & 55.8 & 100 & & \\
\hline \multirow[t]{2}{*}{$\mathrm{V}$} & \multirow{2}{*}{$\begin{array}{l}\text { Bonuses basing on time period worked } \\
\text { affect health workers performance. }\end{array}$} & Freq & 51 & 0 & 15 & 0 & 11 & 77 & \multirow[t]{2}{*}{3.38} & \multirow[t]{2}{*}{1.052} \\
\hline & & $\%$ & 66.2 & 0 & 19.5 & 0 & 14.3 & 100 & & \\
\hline
\end{tabular}

The influence of bonuses on employee performance was investigated and the results presented in Table 4.7 indicates that majority of the respondents disagreed that the hospital provides regularly salary supplements inform of bonus hence improving my efficiency at work as shown with a mean on 2.99 and std.Dev of 1.400. It was also established that the respondents disagreed to the opinion that reallocation of financial incentives like bonuses is done in a transparent manner and fairly (Mean=2.75, std.Dev=1.488). The results further established that payment of bonuses is based on the period of time one has been working in the county(Mean=2.30, std.Dev=1.082). Bonuses payment is related to the output or volume produced (Mean=2.59, std.Dev=1.100). The findings further revealed that the respondents agreed that bonuses basing on time period worked affect health workers performance as shown with a mean of 3.38 and std.Dev of 1.052 .

From the above respondents it can be deduced that most of the respondents were of the opinion that allocation of bonuses was not fairly done and a significant number/percentage disagreed that the hospital has been providing salary supplement regularly in bonus form. This means that the public medical health care workers are not provided with any bonuses as compensation and this in turn affects their performance. The findings concur with the findings of Oyira et al (2015) who found out that bonuses have strong connection with performance of an employee since performance bonuses offer an effective positive influence to both individual and team performance. They observed that rewarding a bonus to employees will eventually enhance the work input of the employee and basically 
encouraging them to work even better in the future. Bonuses motivate an employee to raise his/her performance to attain goals of the business.

\section{Descriptive statistics for Basic Salary on Employee Performance}

The study sought to find out how basic salary affects the performance of employees and find out the extent to which the sub-constructs of basic salary affect employee performance as shown in Table 4.8.

Table 4.8:-Descriptive statistics Results for Basic Salary on Employee Performance

\begin{tabular}{|c|c|c|c|c|c|c|c|c|c|c|}
\hline & Statement & & SA & A & $\mathrm{N}$ & $\mathrm{D}$ & SD & Total & Mean & Std.D \\
\hline \multirow[t]{2}{*}{ I } & \multirow{2}{*}{$\begin{array}{l}\text { The basic salary I earn is } \\
\text { reflective of the work I do and is } \\
\text { adequate to meet my desired } \\
\text { needs and aspirations hence } \\
\text { improving my quality of work. }\end{array}$} & Freq & 15 & 33 & 14 & 15 & 0 & 77 & \multirow[t]{2}{*}{3.25} & \multirow[t]{2}{*}{1.461} \\
\hline & & $\%$ & 19.5 & 42.9 & 18.2 & 19.5 & 0 & 100 & & \\
\hline \multirow[t]{2}{*}{ ii } & \multirow{2}{*}{$\begin{array}{l}\text { Basic Salary raises are regular in } \\
\text { this county hospital thus } \\
\text { affecting my performance }\end{array}$} & Freq & 26 & 5 & 24 & 17 & 5 & 77 & \multirow[t]{2}{*}{3.39} & \multirow[t]{2}{*}{1.329} \\
\hline & & $\%$ & 33.8 & 6.5 & 31.2 & 22.1 & 6.5 & 100 & & \\
\hline \multirow[t]{2}{*}{ iii } & \multirow[b]{2}{*}{$\begin{array}{l}\text { I am satisfied with the amount of } \\
\text { basic salary I earn compared to } \\
\text { other health workers with similar } \\
\text { qualifications hence improved } \\
\text { performance. }\end{array}$} & Freq & 0 & 51 & 0 & 2 & 24 & 77 & \multirow[t]{2}{*}{3.01} & \multirow[t]{2}{*}{1.400} \\
\hline & & $\%$ & 0 & 66.2 & 0 & 2.6 & 31.2 & 100 & & \\
\hline \multirow[t]{2}{*}{ iv } & \multirow{2}{*}{$\begin{array}{l}\text { Basic Salary raises are rare in } \\
\text { this county thus it has affects my } \\
\text { efficiency at work. }\end{array}$} & Freq & 39 & 35 & 3 & 0 & 0 & 77 & \multirow[t]{2}{*}{4.47} & \multirow[t]{2}{*}{0.575} \\
\hline & & $\%$ & 50.6 & 45.5 & 3.9 & 0 & 0 & 100 & & \\
\hline \multirow[t]{2}{*}{$\mathrm{V}$} & \multirow{2}{*}{$\begin{array}{l}\text { Monthly pay is reviewed } \\
\text { occasionally and equitably hence } \\
\text { affecting the performance }\end{array}$} & Freq & 36 & 0 & 21 & 4 & 16 & 77 & \multirow[t]{2}{*}{3.47} & \multirow[t]{2}{*}{1.603} \\
\hline & & $\%$ & 46.8 & 0 & 27.3 & 5.2 & 20.8 & 100 & & \\
\hline
\end{tabular}

According to the findings on table 4.7, the basic salary I earn is reflective of the work i do and is enough to cater for my desirable aspirations and needs hence improving my quality of work as shown by a mean of 3.25 and std.dev of 1.461, basic salary raises are regular in this county hospital thus affecting my performance (mean=3.39, std.dev=1.329), are satisfied with the amount of basic salary earned compared to other public health workers with same qualification hence improved performance (mean=3.01, std.dev=1.400), basic salary raises are rare in this county thus it has affects my efficiency at work (mean=4.47, std.dev=0.575 and monthly pay is reviewed occasionally and equitably hence affecting the performance as shown with a mean of 3.47 and std.dev of 1.603.

From the above findings it can be interpreted that basic salary plays a significant function to the performance of public medical health care workers in the county and ensuring that health staff receive adequate payment for their work is crucial to their loyalty and retention. However, according to the findings, most of the respondents have pointed out that basic salary raises are rare in the county thus it has affected their efficiency at work as shown by the highest mean of 4.47 .

The findings are consistent with a study by Ngure (2017) on the factors that influence retention ofpublic health workers in Kenya with reference to Kenyatta Hospital found out that salary of health workers was not enough in meeting their needs and they were dissatisfied with pay they received for their working when comparing with those with same qualifications outside their institution. However, the results are contradicting and are not in line with a study by Hameed, (2014) who concludes that a fixed pay such as wage has a significant positive effect on satisfaction of a job and increased performance, regardless of the risk preference of an employee. Study by Okoth (2014) on the reward management and its effect on employee performance in North Coast Hotels in Kenya found a 
significant number of employees state that salary payment that is fair is the single most significant thing they need from their organization.

\section{Descriptive statistics for Allowances on Employee Performance}

The study sought to find out how basic salary affects the performance of employees and find out the extent to which the sub-constructs of allowances affect employee performance as shown in Table 4.9.

Table 4.9:-Descriptive statistics Results for Allowances on Employee Performance

\begin{tabular}{|c|c|c|c|c|c|c|c|c|c|c|}
\hline & Statement & & SA & A & $\mathrm{N}$ & D & SD & Total & Mean & Std.D \\
\hline \multirow[t]{2}{*}{ I } & \multirow{2}{*}{$\begin{array}{l}\text { The county hospital offers attractive } \\
\text { allowances to health workers hence } \\
\text { improving their performance. }\end{array}$} & Freq & 0 & 42 & 17 & 18 & 0 & 77 & \multirow[t]{2}{*}{3.08} & \multirow[t]{2}{*}{1.222} \\
\hline & & $\%$ & 0 & 54.5 & 22.1 & 23.4 & 0 & 100 & & \\
\hline \multirow[t]{2}{*}{ ii } & \multirow{2}{*}{$\begin{array}{l}\text { The allowances pay based on unit affect } \\
\text { employee's performance }\end{array}$} & Freq & 0 & 53 & 7 & 0 & 17 & 77 & \multirow[t]{2}{*}{3.25} & \multirow[t]{2}{*}{1.237} \\
\hline & & $\%$ & 0 & 68.8 & 9.1 & 0 & 22.1 & 100 & & \\
\hline \multirow[t]{2}{*}{ iii } & \multirow{2}{*}{$\begin{array}{l}\text { The county does not offer an attractive } \\
\text { allowances hence affecting the health } \\
\text { workers performance }\end{array}$} & Freq & 0 & 53 & 18 & 6 & 0 & 77 & \multirow[t]{2}{*}{3.61} & \multirow[t]{2}{*}{0.632} \\
\hline & & $\%$ & 0 & 68.8 & 23.4 & 7.8 & 0 & 100 & & \\
\hline \multirow[t]{2}{*}{ iv } & \multirow{2}{*}{$\begin{array}{l}\text { The allowances payment based on the } \\
\text { employee skills affects performance of } \\
\text { employees. }\end{array}$} & Freq & 51 & 0 & 10 & 0 & 16 & 77 & \multirow[t]{2}{*}{3.91} & \multirow[t]{2}{*}{1.640} \\
\hline & & $\%$ & 66.2 & 0 & 13.0 & 0 & 20.8 & 100 & & \\
\hline
\end{tabular}

According to the findings on Table 4.9, the county hospital offers attractive allowances to health workers hence improving their performance (mean $=3.08$, std. $d e v=1.222$ ), the allowances pay based on unit affect employee's performance (mean=3.25, std.dev=1.237), the county does not offer an attractive allowances hence affecting the health workers performance (mean $=3.61$, std.dev $=0.632$ ) and the allowances payment based on the employee skill affects performance of employees(mean $=3.91$, std.dev=1.640).

The above results are supported by the findings of Oyira et al (2015) who found that rewards in terms of monetary are tangible returns which included allowances, bonusesincrement and benefitsthat contribute to the positive effect ofperformance of employees. Through adding allowance-earning opportunity, organizations can drive employees to set more goals that are aggressive, working through rejection and obstacles, and to continue to prospect and seekingnew opportunities.

\section{Descriptive statistic of Employee Performance}

The researcher requiredthe respondents' views on the employee performance indicators of public medical health careworkers in the county. The results were as presented on Table 4.10.

Table 4.10:-Descriptive statistic Results for Employee Performance

\begin{tabular}{|c|c|c|c|c|c|c|c|c|c|c|}
\hline & Statement & & SA & A & $\mathrm{N}$ & $\mathrm{D}$ & SD & Total & Mean & Std.D \\
\hline \multirow[t]{2}{*}{ I } & There is improved efficiency among the & Freq & 0 & 48 & 28 & 1 & 0 & 77 & \multirow{2}{*}{3.61} & \multirow[t]{2}{*}{1.222} \\
\hline & health workers in the county. & $\%$ & 0 & 62.3 & 36.4 & 1.3 & 0 & 100 & & \\
\hline \multirow[t]{2}{*}{ ii } & \multirow{2}{*}{$\begin{array}{l}\text { The quality of services given by health } \\
\text { workers within the county is good. }\end{array}$} & Freq & 48 & 1 & 0 & 4 & 24 & 77 & \multirow[t]{2}{*}{3.58} & \multirow[t]{2}{*}{1.237} \\
\hline & & $\%$ & 62.3 & 1.3 & 0 & 5.2 & 31.2 & 100 & & \\
\hline \multirow[t]{2}{*}{ iii } & \multirow{2}{*}{$\begin{array}{l}\text { The attendance of the health workers is } \\
\text { appealing to offer services to the people }\end{array}$} & Freq & 0 & 48 & 0 & 11 & 18 & 77 & \multirow[t]{2}{*}{3.01} & \multirow[t]{2}{*}{0.632} \\
\hline & & $\%$ & 0 & 62.3 & 0 & 14.3 & 23.4 & 100 & & \\
\hline \multirow[t]{2}{*}{ iv } & \multirow{2}{*}{$\begin{array}{l}\text { The health workers at the county offer } \\
\text { efficient and effective quality services. }\end{array}$} & Freq & 50 & 0 & 0 & 12 & 15 & 77 & \multirow[t]{2}{*}{3.75} & \multirow[t]{2}{*}{1.640} \\
\hline & & $\%$ & 64.9 & 0 & 0 & 15.6 & 19.5 & 100 & & \\
\hline
\end{tabular}

The respondents were requested to respond to the statement that there is improved efficiency among the health workers in the county and the results presented on Table 4.10 indicates that majority rated the statement positively and disagreed with a mean of 3.61 and std.dev of 1.222. It was also clear that the quality of services given by health workers within the county is good as shown by a mean of 3.58 and std.Dev of 1.237 , the attendance of the health workers is appealing to offer services to the people (Mean=3.01, std.dev=0.632) and the health workers at the county offer efficient and effective quality services as shown by a mean of 3.75 and std.dev of 1.640. 
These findings are in agreement with the findings of Nyaribo (2016) who found out that efficient and effective quality services of an organization give competitive advantage since it reduces costs and time spent in serving customers. Workers need money to meet their daily demands and that is why they are offering out their services in return of consideration.

Influence of compensation on employee performance

The inferential analysis of the study included the MultipleLinear Regression Analysis as explained below.

MultipleLinear Regression Analysis

The study incorporated the use of MultipleLinear Regression Analysis model to determine if the study variables have any linear relationship between them. The findings are presented as follows;

Table 4.11:-MultipleRegression model Summary

\begin{tabular}{|l|c|c|c|c|}
\hline Model & R & R Square & Adjusted R Square & $\begin{array}{c}\text { Std. Error of the } \\
\text { Estimate }\end{array}$ \\
\hline 1 & $.544^{\mathrm{a}}$ & .692 & .672 & .62125 \\
\hline \multicolumn{2}{|l}{ a. Predictors: (Constant), Allowances, Basic Salary, Bonuses } \\
\hline
\end{tabular}

The results in Table 4.11 presents the model summary of multiple regression clearly indicating an influence that is positive of compensation scheme and employee performance as illustrated by a positive correlation of R-0.544 and $\mathrm{R}^{2}$ of 0.692 . The coefficient of determination value of 0.692 denotes that $69.2 \%$ of employee performance in Vihiga county deviation is brought about the mentioned compensation (Allowances, Basic Salary, Bonuses) while the remaining portion of $30.8 \%$ is accounted by other factors not mentioned in the study.

Assessing the Fit of MultipleRegression Model

Table 4.12:-Anova Test Results

\begin{tabular}{|l|l|c|c|c|c|c|}
\hline Model & Sum of Squares & df & Mean Square & F & Sig. \\
\hline \multirow{3}{*}{1} & Regression & 11.709 & 3 & 3.903 & 10.112 & $.000^{\mathrm{b}}$ \\
\cline { 2 - 7 } & Residual & 27.788 & 72 & .386 & & \\
\cline { 2 - 7 } & Total & 39.497 & 75 & & & \\
\hline \multicolumn{2}{|l|}{ a. Dependent Variable: Employee Performance } \\
\hline
\end{tabular}

The study results indicated that the influence of the independent variables (Allowances, Basic Salary, Bonuses) on the dependent variable (Employee performance)

Which according to the results shows the variables were statistically significant with $(\mathrm{F}=10.112 ; \mathrm{p}<0.05)$. The results therefore indicates that the MultipleRegression analysis model was fit for the date and therefore Allowances, Basic Salary, Bonuses have a great influence on performance of employees who are the public medical health care workers in vihiga county.

\section{Regression Coefficients}

Regression coefficients measure the extent of dependence of one variable on the others. Beta $(\beta)$ was determined through performing T-test of statistical significance of each regression coefficient to establish how strongly each independent variable affects the dependent variable and the results obtained were as shown in Table 4.13.

Table 4.13:-RegressionCoefficients

\begin{tabular}{|c|c|c|c|c|c|c|c|c|}
\hline \multirow{2}{*}{\multicolumn{2}{|c|}{ Model }} & \multicolumn{2}{|c|}{$\begin{array}{l}\text { Unstandardized } \\
\text { Coefficients }\end{array}$} & \multirow{2}{*}{$\begin{array}{c}\begin{array}{c}\text { Standardized } \\
\text { Coefficients }\end{array} \\
\text { Beta }\end{array}$} & \multirow[t]{2}{*}{$\mathbf{t}$} & \multirow[t]{2}{*}{ Sig. } & \multicolumn{2}{|c|}{$\begin{array}{c}\text { Collinearity } \\
\text { Statistics }\end{array}$} \\
\hline & & B & $\begin{array}{c}\text { Std. } \\
\text { Error }\end{array}$ & & & & Tolerance & VIF \\
\hline \multirow[t]{4}{*}{1} & (Constant) & .541 & .617 & & 2.076 & .384 & & \\
\hline & Bonuses & .234 & .126 & .256 & 2.088 & .031 & .909 & 1.100 \\
\hline & Basic Salary & .346 & .108 & .354 & 2.445 & .019 & .975 & 1.026 \\
\hline & Allowances & .257 & .143 & .265 & 2.871 & .000 & .907 & 1.102 \\
\hline
\end{tabular}


Table 4.13 displays the results of regression coefficients whereby bonuses had a positive and significant influence on employee performance with $(\beta=0.234 ; \mathrm{p}<0.05)$, basic salary had a positive and significant influence on employee performance with $(\beta=0.346 ; p<0.05)$ and allowances had positive and significant influence on employee performance with $(\beta=0.257 ; \mathrm{p}<0.05)$.

Thus, the multiple regression equation was developed from the coefficients as follows; $\mathrm{Y}=0.541+0.234 \mathrm{X}_{1}+0.346 \mathrm{X}_{2}+0.257 \mathrm{X}_{3}$

From the findings of the regression analysis if all indicators (Allowances, Basic Salary, and Bonuses) were held constant, performance of employee would be at 0.541. A unit increase in bonuses would lead to a unit increase in performance of employee by 0.234 . A unit increase in basic salary would lead to an increase in unit of employee performance by 0.346. A unit increase in allowances would lead to a unit increase in performance of employee by 0.257. All the indicators were significant as $\mathrm{p}$ values were less than 0.05.The findings concurs with that of Shields and Ward (2011) who used a cross-sectional data of nurses in Britain and found that allowances, salary, commission, bonuses and promotion have a stronger effect on employee's satisfaction which leads to improved performance.

\section{Discussions of the study Findings:-}

The discussion of findings presents theory explanation in relation to the influence of compensation scheme on employee performance of public medical health care workers of Vihiga county Government. Expectancy theoryis concerned and is related to how the behaviour of an individual is as a consequence of what they believe in and that their decision might lead to some outcome or particular design. It expounds on how the employee expectation of reward that is equal to the organizational input and the second dimension is the organizational expectation of an output by the employee that is equal to the reward given. The findings of this study have supported Expectancy theory since compensation schemes affects performance of employees since an organization has put up rewards (compensation) that are supposed to be attractive in achieving a desirable outcome which is performance.

Equity theory is centered on perceived individual fairness in an organization. An employee will reflect on the effort and how much he has applied and will compare this to what he/she gets from it. After evaluating this individually of his/her ratio of input- output he will then be comparing his ratio to the input- output ratio of others, especially the direct colleagues or peers. The findings of the study support this theory since it highlights theneed for equality and equalization in paying the employee tends to motivate them to feel appreciated and increases their performance.

Reinforcement theory explains that a response followed by a compensation/reward will more likely to happen again in future since a behaviour which has an experience that is rewarding there is a possibility of being repeated. The findings of the study support the theory since it has shown that compensation can become an obtained right if they are issued regularly. Compensation scheme if well considered in an organization, thenhigh employee performance will be experienced.

\section{Summary of the Findings}

The main objective of this study was to investigate the influence of compensation scheme on employees' performance thus this section entails the summary of findings in relation to the objectives of the study.

The study determined the relationship and influence of bonuses given and the performance of employees. The study results of the study revealed that there is a significant positive relationship between bonuses and the performance of employees at Vihiga County. The study further indicated that majority of the respondents disagreed that the hospital provides regularly salary supplements inform of bonus hence improving their efficiency at work. It was also established that the respondents disagreed to the opinion that reallocation of financial incentives like bonuses are done in a transparent manner and fairly, payment of bonuses is based on the period of time one has been working in the county, bonus payment is based on the output and volume produced. The findings further revealed that the respondents agreed that bonuses basing on time period worked affected health workers performance. Therefore, giving employees financial compensation such as bonuses the results points out with clarity that this influences the performance of employees.

The study findings discovered that basic salary has an influence which is positive and significant on the performance of employees who arepublic medical health care workers that are found in VihigaCounty. Furthermore the findings showed that majority of the public medical health care workers indicated thatbasic salary raises are rare in the county thus it has affected their efficiency at work. In addition, the basic salary the public medical health workers earn is reflective of the work they do and is adequate to meet their desired needs and aspirations hence improving 
their quality of work, basic salary raises are regular in the county hospital thus affecting their performance, medical health workers in Vihiga county are satisfied with the amount of basic salary they earn comparing to other health workers with same qualifications hence improved performance and monthly pay is reviewed occasionally and equitably hence affecting the performance.

The results obtained from the study signify that allowances have a significant and positive influence of performance of employees at the county. The findings further revealed that the allowances pay based on the employees' skills affects employee's performance, the county hospital offers attractive allowances to health workers hence improving their performance, the allowances pay based on unit affect employee's performance and that the county does not offer an attractive allowances hence affecting the health workers performance.

\section{Conclusion:-}

The study concluded that compensation scheme influences the performance of public medical healthcare workers of Vihiga County Government positively. The study further concluded that bonuses has an influence on employee performance however the county hospital does not provide regularly salary supplements inform of bonus hence affecting their efficiency at work. Further it was concluded that basic salary raises are rare in the county thus it has affected their efficiency at work. Lastly it was concluded that allowances pay based on the employees skill employee affects employee's performance and that the county offers attractive allowances to health workers hence improving their performance.

In relation to the theories (expectancy theory, equity theory and reinforcement theory) of the study the study supports all the theories since they have shown that compensation schemes affects performance of employees since an organization has put up rewards (compensation scheme) that are supposed to be attractive in achieving a desirable outcome which is performance. There is also the need for equality in paying health workers and thistends to motivate them to feel appreciated and increases their performance.

\section{Recommendations}

Based on the findings, the study gives the following crucial recommendations for policy and practice:

The researcher recommends that allowances should awarded in a way that is fair to all cadres of staff and job evaluation should be conducted in order to enhanceharmonization of salary.

To the government, the study recommends that they should have in place procedures, measures and guidelines that oversee how county governments operate more so on issues relating to compensation schemes.

The government, county government of Vihiga and other counties should consider reviewing the basic salary pay of medical health workers on a yearly basis since this will assist in retaining the employee in the county for long, enhance their loyalty and improve their performance.

The study recommends that county governments should consider finding means of paying bonuses to the employeesespecially publicmedical health workers as a way of enhancing their performance in terms of service delivery.

Based on expectancy theory, the researcher recommends that county governments should ensure the medical health workers are compensated based on the volume or number of units produced and organizational input. Based on equity theory the management of county governments should ensure that all employees are compensated equally to improve and increase their performance.

\section{Limitations of the Study}

A number of limitations were identified in the conduct of this study. First the study was limited to the problem of compensation schemes and how it influences the performance of public health care workers among other problems and challenges facing the health workers in county governments. The public health care workers are not only having problems with payment but are also affected by other factors which in turn affect their performance at work. Secondly the study was limited to the public healthcare workers in Vihiga county government only therefore the findings may not be applicable to other counties. 
Finally, the study used Cross sectional survey. Cross sectional survey is limited in accuracy due to the fact that it is a snap shot at a point of time. Despite this limitation accuracy and validity of results was enhanced as the data was obtained by questionnaires administered personally. Besides, data collection instrument comprised of questions which was self administered.

\section{Suggestions for Further Research}

In relation to further studies, the study suggests that future researchers need to carry out a study on the mediating influence on the association between compensation scheme and performance. The study further suggests that more research needs to be done on the same area but concentrate on other factors influencing employee performance of county governments and even the private sector such as banks and manufacturing companies for the purpose of comparing.

\section{References:-}

1. Adams, J.S (1965).Inequity in social exchange.In L. Berkowitz (ed.), Advances in experimental social psychology. New York: Academic Press.

2. Agarwal, N. C. (2008). Reward Systems: Emerging Trends \& Issues. Academic Journal Article: Canadian Psychology. Retrieved from http://findarticles.com

3. Ahmed, S., Ullah, A., \& Ahmed, I. (2015).Relationship between Employee Job Satisfaction and Turnover Intention in Microfinance Banks in Pakistan.Paradigms.32 (3), 30-38.

4. Akers, H. (2018). Salary Increment.Antioch University, Los Angeles.

5. Ali, A. A., Edwin, O., \&Tirimba, O. I. (2015). Analysis of Extrinsic Rewards and Employee Satisfaction: Case of Somtel Company in Somaliland. International Journal of Business Management \& Economic Research, 6(6), 16-25.

6. Armstrong, M., \& Taylor, S. (2014). Armstrong's handbook of human resource management practice.Kogan Page Publishers.

7. Aslam, A., Ghaffar, A., Talha, T., \&Musthaq, H. (2015). Impact of compensation and reward system on the performance of an organization: An empirical study on banking sector of Pakistan. European Journal of Business and Social Sciences, 4(8), 51-53

8. Biron, M,\&Bamberger,P.(2011).More than Lip Service: Linking the Intensity of Empowerment Initiatives to Individual Well- Being and Performance, International Journal of Human Resource Management, 22, (2), 258278.

9. Buford, S. (2006).Linking Human Resources to Organisational Performance and Employee Relations in Human Service Organisations: Ten Human Resource Essentials for Managers Routlege London UK.

10. Cole, G.A (2011). The administration theory and workers motivation, Zanta Institute of administration press Ltd.ABU Zaria, Nigeria.

11. Condly, S. J., Clark, R. E., \&Stolovitch, H. D. (2013). The Effects of Incentives on Workplace Performance: A Meta-analytic Review of Research Studies. Performance Improvement Quarterly, 16(3), 5-18.

12. Dash, M., Singh, A., and Vivekananda. (2008). Motivation in ITES industry: Dimensionality with reference to Hertzberg's theory. ICFAI Journal of Organizational Behavior, 7 (2).

13. Ekerman,G.(2010). Job Enrichment and staff Motivation, Human Resource Management.Cape Town: Maskew Miller Longman(Pvt) Ltd.

14. Greenberg ,J.and Baron R.A.(2003).Behaviour in Organizations; Understanding and Managing the Human Side of Work. Englewood Cliffs, NJ: Prentice.

15. Hakala, D. (2016). How to Measure Employee Performance, 16 Ways.HR World Newsletter. Retrieved from http://www.hrworld.com/features/16-ways-measure-perfromance-021908/

16. Hameed, A., Ramzan, M., Zubair, H. M. K., \& others.(2014). Impact of compensation on employee performance (empirical evidence from banking sector of Pakistan). International Journal of Business and Social Science, 5(2).

17. Heathfield, W. (2017).Salary Increment.Havard Business School.University of Pittsburgh.

18. Kabiru, C. (2018). The effects of compensation system on employee's performance in microfinance institutions in Nyeri County, Kenya.Kenyatta University.

19. Karanja, S.(2012).Effects of reward system on Employee Performance of Cooperative Bank headquarter; Nairobi Kenya.

20. Kariuki, P., (2014).Corruption Devolved to the Counties, Daily Nation, 4 April, Nairobi.

21. Kitchenham, B., \&Pfleeger, S. L. (2002). Principles of survey research: part 5: populations and samples. ACM SIGSOFT Software Engineering Notes, 27(5), 17-20. 
22. Kothari, C.R. (2004). Research Methodology: Methods and Techniques $2^{\text {nd }}$ Edition. New Age Publishers. India.

23. Latham, G., (2015). A theory of goal setting and task performance.

24. Lotta V. (2012), Returns to inventors. Review of Economics and Statistics, 94(4), 1173-1190.

25. Lunenburg, F.C. (2011). Expectancy Theory of Motivation: Motivating by Altering Expectations. International Journal ofBusiness Administration, 15(1),1-6

26. Mamdani, K. F., \&Minhaj, S. (2014). Effects of Motivational Incentives on Employees' performance: A Case Study of Banks Of Karachi, Pakistan.

27. Markova, G., \& Ford, C. (2014). Is money the panacea? Rewards for knowledge workers. International Journal of Productivity and Performance Management, 60(8), 813-823.

28. Muchiri, H. (2016). Effects of Rewards on Employee Performance in the Hospitality Industry: A Case of Nairobi Serena Hotel. United States International University-Africa.

29. Mugenda, O.\&Mugenda, A,(2003).Research methods; Quantitative and qualitative approaches. Nairobi: Act press, 2, 76- 81 .

30. Nassiuma, K. (2000). Survey Sampling: Theory and methods. Nairobi: University of Nairobi press.

31. Ndetei, D., Khasakhala, L. and Omolo, J. (2015).Incentives for health worker retention in Kenya: An assessment of current practice.Africa Mental Health Foundation (AMHF), Institute of Policy Analysis and Research (IPAR), Kenya.

32. Nnaji-Ihedinmah, N. C., \&Egbunike, F. C., (2014).Effect of Rewards on Employee Performance in Organizations: A Study of Selected Commercial Banks in Awka Metropolis.

33. Nyaribo, O. L., (2016). The Effect of Non-Financial Compensation on EmployeePerformance of Micro-Finance Institutions: A Case of WakenyaPamojaSacco,Kisii County, Kenya. Imperial Journal of Interdisciplinary Research, 6 (2), 15-30.

34. Ojeleye, S. (2017).study on the Impact of Remuneration on Employees' Performance of Abdul Gusau Polytechnic, Talata-Mafara and State College of Education Maru, Zamfara State. Arabian Journal of Business and Management Review. 67(2), 15-22.

35. Okoth, N. H., (2014). Effects of reward management on employee performance in Hotels in north coast, Kenya. School of business, University of Nairobi.

36. Okumbe, J.A.(1998). Education Management. Theory and practice Nairobi: University Press.

37. Opu, S.(2008). Motivation Measures and Improving Workers Performance in Kitgum district Uganda.

38. Owusu T. (2012).Effects of motivation on employee performance, Ghana Commercial Bank, kumasi zone, Master thesis,51- 87.

39. Oyira E.J, Regina, E., Nkamare, S., Lukpata, F., Uwa, L. and Awok, P. (2015). Effect of reward system among health care workers performance: a case study of university of Calabar teaching hospital Calabar, Nigeria. Journal of Hospital Administration. 4(3) 30-55.

40. Pierce et al (2004) Effects of Pay Level on organizational based Performance. Journal of Occupational and Organizational Psychology (2004), 77, 307-322.

41. Porter, L.W. and Lawler, E.E. (2008).Managerial Attitudes and Performance. Homewood, IL: Dorsey Press.

42. Pradesh, India. Science, Technology and Arts Research Journal, 2(4), 122.

43. Prasetya, A., \& Kato, M. (2014). The effect of financial and non-financial compensation to the employee performance.Thesis, Asia Pacific University, Japan. Retrieved from http://www.studymode.com

44. Reddy, S., \&Karim, S. (2014).Impact of Incentive Schemes on Employee Performance: A Case Study of Singareni Collieries Company Limited, Kothagudem, Andhra

45. Redmond, G.G.(2009).The relationship of satisfiers and dissatisfiers to productivity, turnover and morale, American Psychologists ,20,499-502.

46. Rehmanm M. S. (2009). Impact of Job Analysis on Job Performance, Springer

47. Richard, B. (2014). The effect of motivation on employees' performance: empirical evidence from the brongahafo education directorate. Citeseer.

48. Robbins, S., Judge, T., \&Sanghi, S. (2015). Organizational Behavior $\left(13^{\text {th }}\right.$ ed.).NewDelhi: Pearson Education.

49. Shilongo, H. N. (2013). The impact of performance related pay on employees-A casestudy of the performance incentive bonus scheme at the Motor Vehicle Accident Fund

50. Skinner, B. F. (1953).Science and Human Behavior. New York: Free Press

51. Storey, J. (2005)."Making European managers: an overview", Human Resource Management Journal, (3) 1, 111.

52. Surbhi, S. (2015). Differences between Salaries and Wages. Retrieved on $24^{\text {th }}$ August , 2016. 
53. Thuita, G., and Oiye, Y. (2018). Compensation, working conditions and employee satisfaction in Kilifi export processing zones, Kenya. International Journal of Economics, Business and Management Research.2(2), 24567760 .

54. Vroom, V.H. (1964).Work and motivation. New York: Wiley.

55. Whitener, E.M., Brodt, S.E., Korsgaard, M.A., Werner, J.M. (2008), "Managers as initiators of trust: an exchange relationship framework for understanding managerial trustworthy behavior", The Academy of Management Review, (23) 3, 13-30.

56. Wong, P. \& Wong, B. (2009). The Dance of Change: The Challenges of Sustaining Momentum in Learning Organisations. New York, USA: Doubleday. 